\title{
Study on parameters on cutting AAC by wires
}

\section{Tung T. Luu*}

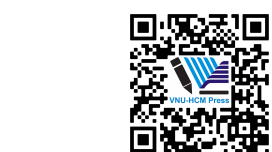

Use your smartphone to scan this QR code and download this article

Ho Chi Minh city University of Technology - VNU-HCM, Vietnam

Correspondence

Tung T. Luu, Ho Chi Minh city University of Technology - VNU-HCM, Vietnam

Email: ttluu@hcmut.edu.vn

History

- Received: 18-11-2020

- Accepted: 16-3-2021

- Published: 30-3-2021

DOI : 10.32508/stdjet.v4i1.795

\section{Check for updates}

\section{Copyright}

(1) VNU-HCM Press. This is an openaccess article distributed under the terms of the Creative Commons Attribution 4.0 International license.

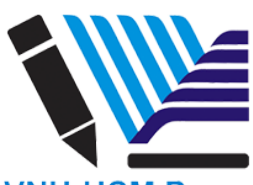

VNU-HCM Press

\begin{abstract}
Autoclaved Aerated Concrete (AAC) is a building product with light weight, High insulation, durability and well load bearing, which is produced with many kinds of sizes and strengths. AAC Blocks is light weight one when compared with red bricks. The red bricks are about three times heavier than the AAC blocks. AAC block is rapidly developing in Vietnam. The block has more advantages such as precast, and easy installation. AAC is manufactured by the common materials such as: sand, lime, water, cement, and a little rising agent. Then, the mixture is mixed and molded, it is autoclaved in an oven with heat and pressure to create unique properties. After that, the AAC block will be cut into block brick by steel wire. When cutting the ACC block, the block brick surface must be smooth so that it is unnecessary to mortar. Furthermore, the roughness of the surface must be smaller than $0.1 \mathrm{~mm}$ to paint the wall easily. The block dimension also needs high precision so that the wall will be straight when blocks are superposed. However, in this paper, the roughness of the block surface will be only researched because the roughness will decide the cost, and the dimension decide the estheticism of the wall. The block is made by using steel wires to cut big AAC blocks into small blocks. Influences of working parameters on the steps of the steel wire sawing processes are feed rate, wire speed and tension. Each parameter will affect surface quality with different effects. Besides, these parameters affect each other, which causes scratches on the AAC surface. Experiments will be made to measure the height of roughness with the change of wire speed, feed rate and tension. The best parameters will be found, which helps the AAC manufacturer to obtain the higher quality.
\end{abstract}

Key words: Autoclaved Aerated Concrete, steel wire, roughness

\section{INTRODUCTION}

The AAC material was made in Sweden in 1924. In Europe, it has become the most well-known building materials and is rapidly developed in a lots of countries in the world. AAC is made from the materials found easily such as: sand, lime, water, a little rising agent and cement. After the mixture is mixed and molded, it is autoclaved in an oven with reasonable pressure and heat to create unique properties. AAC possesses the excellent quality of thermal insulation and acoustic absorption and. AAC also have ability of pest resistant and fire. AAC is competitively and environmentally superior to traditional building materials such as wood, stone, concrete and brick. When AAC is cast and mixed in structures, a few compound reactions occur that make AAC light (The AAC density is $20 \%$ of cement one) and warm properties. Aluminum powder in compound reacts with water and calcium hydroxide to produce hydrogen gas. The hydrogen gas is created and makes the volume of the blend rise to $3 \mathrm{~mm}$ in the surface. When the frothing procedure has finished, the hydrogen escapes from the compound and the air supplanted these position.
When the compound forms are removed from the mould, they are in solid state but rather soft. They will be cut into either panels or blocks and put in a chamber with heat and pressure during 12 hours. The steel wires are often used to cut. During hardening process under steam pressure, the temperature will obtain $190^{\circ}$ Celsius and the team pressure will be from 8 to 12 bars. Quartz sand reacts with calcium hydroxide to produce calcium silicate hydrate. This process gives AAC high strength and unique properties. Although the processing temperature is about $200^{\circ} \mathrm{Cel}$ sius, AAC blocks are not classified as fired brick but a lightweight concrete masonry unit. When the autoclaving process has finished, the ACC block is immediately ready for use on the construction work. Depending on processing and ratio of material, its density can reach to $80 \%$ of air in an AAC block. However, AAC with low density often have low compression strength. The maximum load of AAC can reach to $8 \mathrm{MPa} \sim 1,160 \mathrm{PSI}$, it equals $50 \%$ of the compressive strength of concrete.

As mentioned above, the ACC will be cut by steel wire with diameter of 0.5 to 0.8 millimeter. When cutting, parameters consisting of wire speed, feed rate and ten- 
sion will be determined to obtain the lowest roughness. Almost kinds of brittle materials (including concrete, rocks and ceramics) and wood can be sawed by using a steel wire with smooth surface ${ }^{1}$. The vibration of wire is mentioned, which the damped frequencies of the cutting wire will increase when the contact span is larger ${ }^{2}$. This problem makes the resonant change and then the roughness will increase. The pressure on the block is permanent ${ }^{3}$. As the speed of the wire increases, the number of cutting diamond grains in a second increases and the depth of the diamond grains into granite will decrease. The cutting efficiency will increase obviously and the cutting force decreases remarkable. This leads to the low roughness. It is said, the amplitude of vibration of the wire saw manufacturing process needs minimizing across a spectrum of excitation frequencies to decrease the kerf loss ${ }^{4}$. The analysis of frequency spectrum says that it is very effective to increase the tension of wire for reducing the vibration amplitude and kerf loss than to change the speed of the wire. When the tension of wire is increased, the stiffness of the system is also increased, as result of the reduction of kerf loss. The width of the cutting zone is always greater in the forward direction than in the backward direction because the longer wire travel distance associated with the forward direction $^{5}$. The cutting zone width (CZW) near the wire entry region is almost always greater than that the wire exit for both cycle schemes. The CZW varies in the feed direction, the forward motion direction often makes the CZW bigger. That means that the cutting zone width will decrease from the bottom to the top of the compound. In another reference, the wire cutting is experimented and the Taguchi method was used to select the best parameters to get a lowest roughness ${ }^{6}$. It is said that the smaller the grain size combined with a fast wire speed and low feed rate delivered a much better surface roughness. It is understood when grain size is lager, the wire speed and the feed rate is faster and with the slurry, the material removal rate is better. When the grain size is smaller, kerf width will be better. This is because when the grain size is bigger, diameter in the saw is larger.

In problems of wire cutting, if the cut material is different, the parameters will be different. However, their characteristics are almost same such as fast speed wire, increasing feed rate, wire tension, which leads to a change of roughness. In this paper, the steel wire will be used to cut AAC. Three parameters must be determined to find optimal ones. Experiments will be done with a cutting machine in which the steel wires were fixed on a steel frame moving forward and backward. When the parameters said above are measured, the statistical data will be found. Based on them, the optimal parameters will be shown.

\section{EXPERIMENT EQUIPMENT}

In the Figure 1, the structure of the cutting wire system is shown. This machine consists of a steel frame can move forward and backward on linear bearings. These linear bearings make the movement of the frame smooth, which prevents unnecessary vibrations from affecting the cutting wire. A motor with gearbox will make an eccentric shaft rotate. This shaft together with connecting rod will cause the steel frame movement. This structure is the model of slider-crank linkage.

However, if there is one steel frame, this machine will vibrate strongly. This occurs because the slider-crank linkage is difficult to balance. To reduce this vibration, two steel frames are rebuilt so that they will be symmetric. Because vibration forces produced in period of the frame movement decrease, the cut surface qualify will be better.

The feeder rate will be performed by a hydraulic cylinder. The cylinder will make the steel frame go up or down. The feeder rate will be controlled by a restrictor valve. When adjusting the restrictor, the feeder rate will change. The lifting or lowering velocity of the steel frame will represent the feeder rate. Thus, the velocity parameter is equal to the feeder rate one. The cutting wire is hung on the steel frame. When the steel frames move, they make the wires move and cut the block, Figure 2. In order to cut the block, three parameters must be determined: the tension of the wire, the speed of the wire, and the lowering velocity. The tensions of wires are produced by leaf springs. There are two leaf springs fixed at two ends of wire. One end of the leaf spring is connected with the steel frame and the other with the cutting wire. The wire tension can adjust up or down by a bolt and nut.

\begin{tabular}{ll} 
Table 1: Manufacturing condition of cutting wire \\
\hline Parts & Material and Dimension \\
Cutting wire & Steel \\
Diameter of wire & $0.5 \mathrm{~mm}$ \\
Tension strength & 5 to $20 \mathrm{kgf}$ \\
Movement distance. & $150 \mathrm{~mm}$ \\
Swing frequency & 20 to $40 \mathrm{~Hz}$ \\
Lifting and lowering ve- & 3 to $20 \mathrm{~meter} /$ minute. \\
locity & \\
Swing frequency & $20 \mathrm{~Hz}$. \\
\hline
\end{tabular}




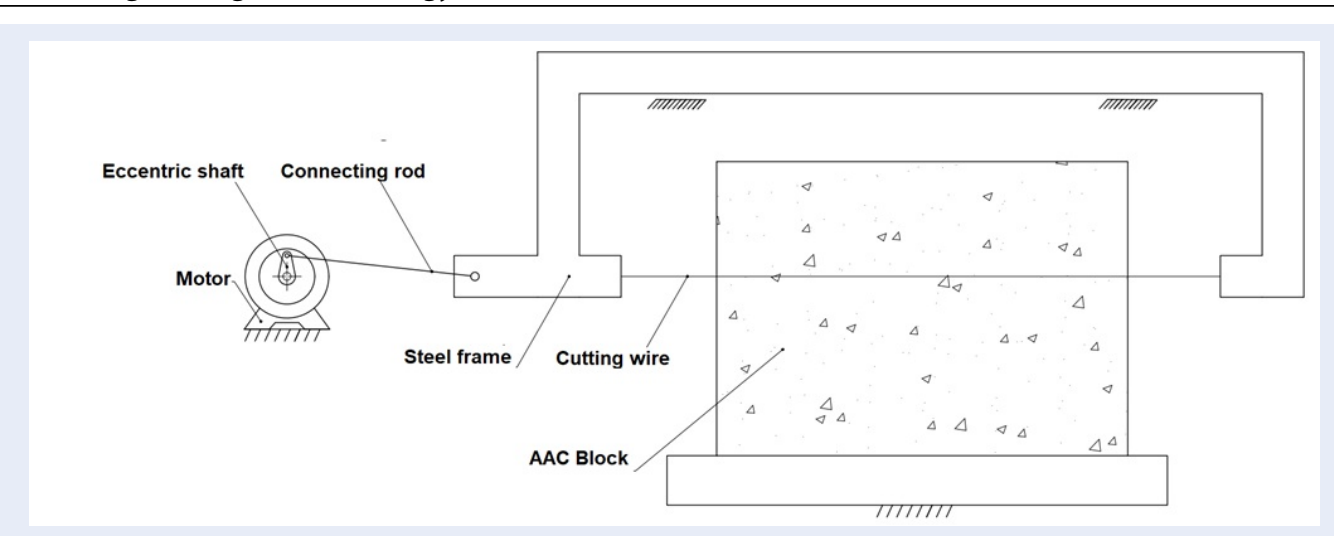

Figure 1: Structure of the cutting wire system.

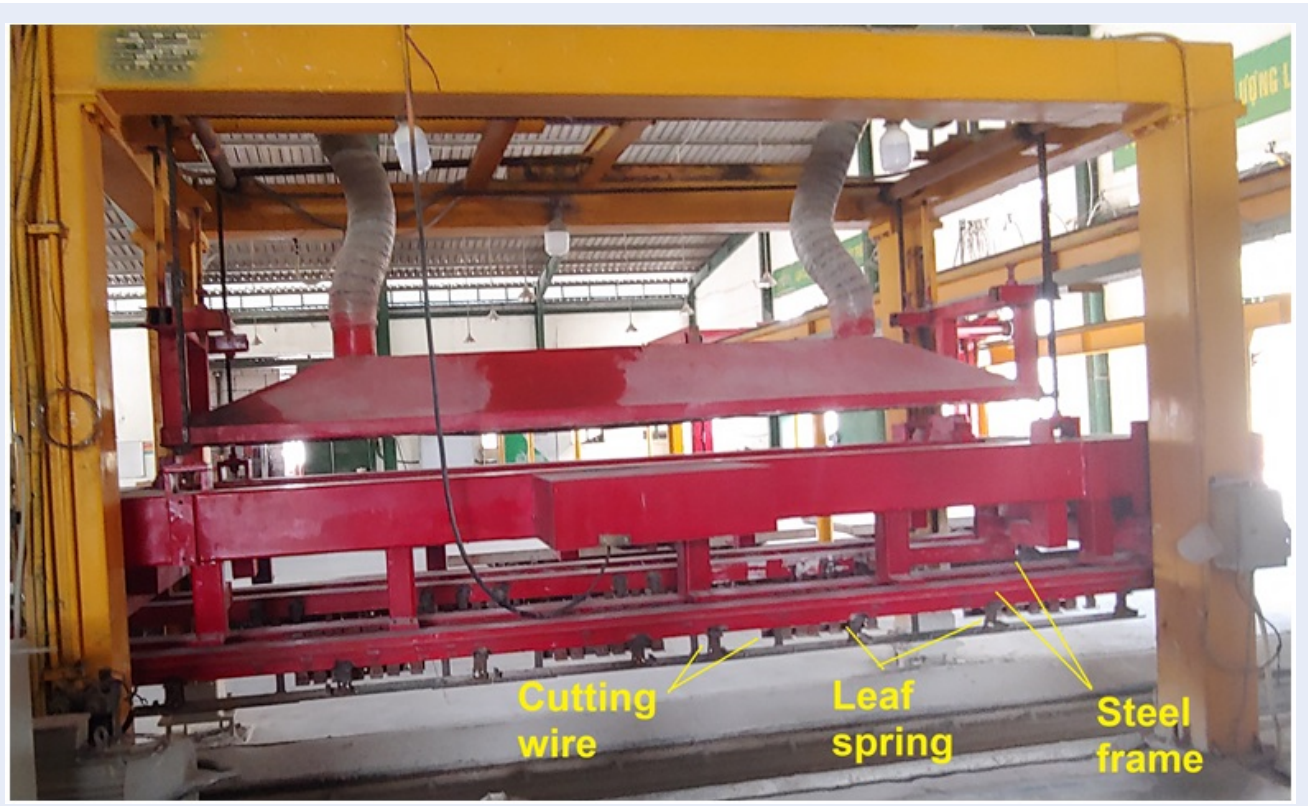

Figure 2: Real structure of the cutting wire system.

The manufacturing conditions of cutting the block is displayed in Table 1 . Three parameters needing to find optimization consist of tension strength, cutting velocity, feeder rate. To change the tension strength, the bolts will be adjusted. The tension can change from 5 to $20 \mathrm{kgf}$. To change the cutting velocity, swing frequency will be adjusted by an inverter which controls a motor. Last one, the feeder rate is changed by a hydraulic restrictor valve that raises or lowers the steel frame.

\section{EXPERIMENT METHOD}

The AAC block will be produced from mixture of cement, clay, sand, and hydrogen gas. This mixture is put in mould during one to two hours. This time, the blocks become soft and spongy. Then, they are sent to the cutting machine. The experiment will be made here. Three parameters will change to find the regression equation. After cutting, the block is heated to 120 Celsius degrees and become hard after 1 day. The AAC block is separated into small bricks. The roughness will be measured by Surface Roughness Tester as shown in Figure 3.

Data of the experiment consists of the inputs: tension, swing frequency, lowering velocity and output: Roughness. The values of input will be showed in Table 2 .

From the experimental data, the diagrams of tension versus toughness are shown in the Figure 4 . The re- 


\begin{tabular}{|c|c|c|c|c|}
\hline No & Tension & Swing frequency $(\mathrm{Hz})$ & Lowering velocity $(\mathrm{m} / \mathrm{m})$ & roughness $(\mathrm{mm})$ \\
\hline 1 & 5 & 20 & 5 & 220 \\
\hline 2 & 5 & 20 & 12 & 300 \\
\hline 3 & 5 & 20 & 20 & 320 \\
\hline 4 & 5 & 30 & 5 & 200 \\
\hline 5 & 5 & 30 & 12 & 410 \\
\hline 6 & 5 & 30 & 20 & 340 \\
\hline 7 & 5 & 40 & 5 & 150 \\
\hline 8 & 5 & 40 & 12 & 330 \\
\hline 9 & 5 & 40 & 20 & 320 \\
\hline 10 & 10 & 20 & 5 & 210 \\
\hline 11 & 10 & 20 & 12 & 280 \\
\hline 12 & 10 & 20 & 20 & 310 \\
\hline 13 & 10 & 30 & 5 & 180 \\
\hline 14 & 10 & 30 & 12 & 420 \\
\hline 15 & 10 & 30 & 20 & 350 \\
\hline 16 & 10 & 40 & 5 & 150 \\
\hline 17 & 10 & 40 & 12 & 360 \\
\hline 18 & 10 & 40 & 20 & 360 \\
\hline 19 & 15 & 20 & 5 & 205 \\
\hline 20 & 15 & 20 & 12 & 270 \\
\hline 21 & 15 & 20 & 20 & 305 \\
\hline 22 & 15 & 30 & 5 & 180 \\
\hline 23 & 15 & 30 & 12 & 345 \\
\hline 24 & 15 & 30 & 20 & 345 \\
\hline 25 & 15 & 40 & 5 & 160 \\
\hline 26 & 15 & 40 & 12 & 345 \\
\hline 27 & 15 & 40 & 20 & 345 \\
\hline
\end{tabular}

sults are same as that of reference ${ }^{1-6}$. When the tension is increased, the stiffness of the system is also increased, as a result that the roughness reduces. These problems are illustrated in Figure 4. However, the tension is not infinite growth. The growth of tension does not result in better surface ${ }^{3}$. It is only sound in a gap of tension. The roughness seems not to decrease when the tension is more than $16 \mathrm{kgf}$.

The damped frequencies of the system decrease slightly when the wire speed increases ${ }^{4}$. As a result, the vibration amplitude reduces and the surface will be smoother. In other words, the roughness will de- crease. This phenomenon is explained in Figure 5.

When the lowering velocity increase, the surface seems more terrible (Figure 6). This conclusion is said $\left({ }^{4}\right)$ that the lower wire speed is desirable in reducing the vibration of the wire. In other words, the increase of lowering speed make the wire vibrate stronger and the surface rougher. 


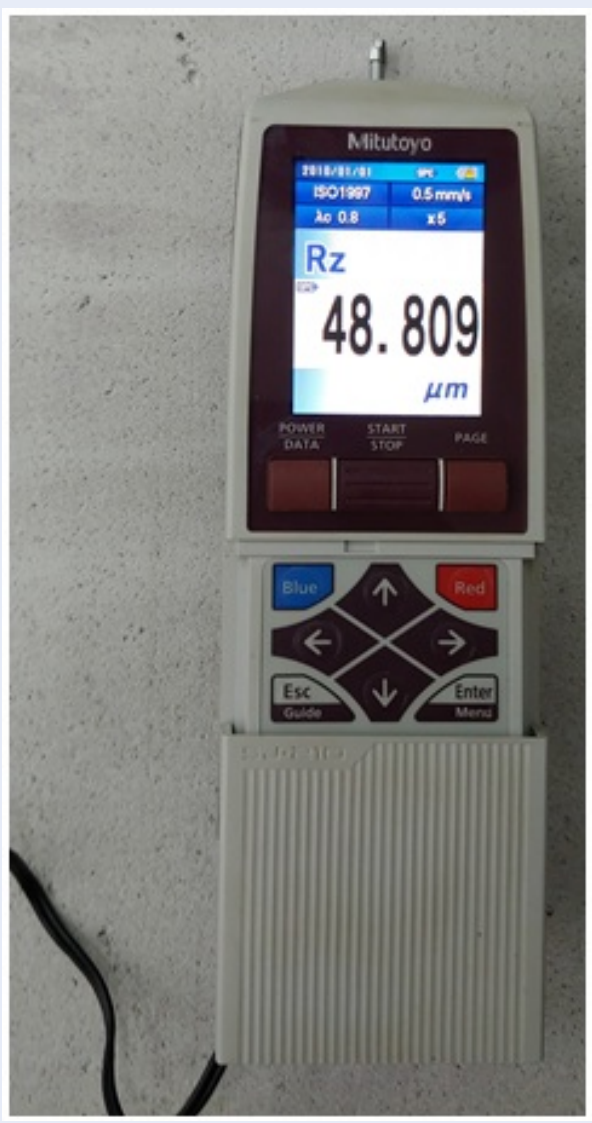

Figure 3: Surface roughness tester

\section{ANALYSIS OF VARIANCE (ANOVA) AND CORRELATIVE COEFFICIENT OF CUTTING PARAMETERS}

The ANOVA help to find out which cutting parameters influence the result of performance. It is done by separating the total variability of the relational grades. This work is done by the total of the squared deviations with the total mean of the relational grade, into contributions by each the error and cutting process parameters.

This research was made on an ANOVA of data with the wire tension, the swing frequency and the lower velocity. The objective of analyzing the effective of three group data is each data group will be independent or dependent. This analysis was done for a level of significance of $5 \%$, that means it obtain the confidence of $95 \%$. The Table 3 showed that the data groups: the wire tension, the swing frequency and the lower velocity are independent of each other.

In 3 data groups, the wire tension, the swing frequency and the lower velocity, which group plays an

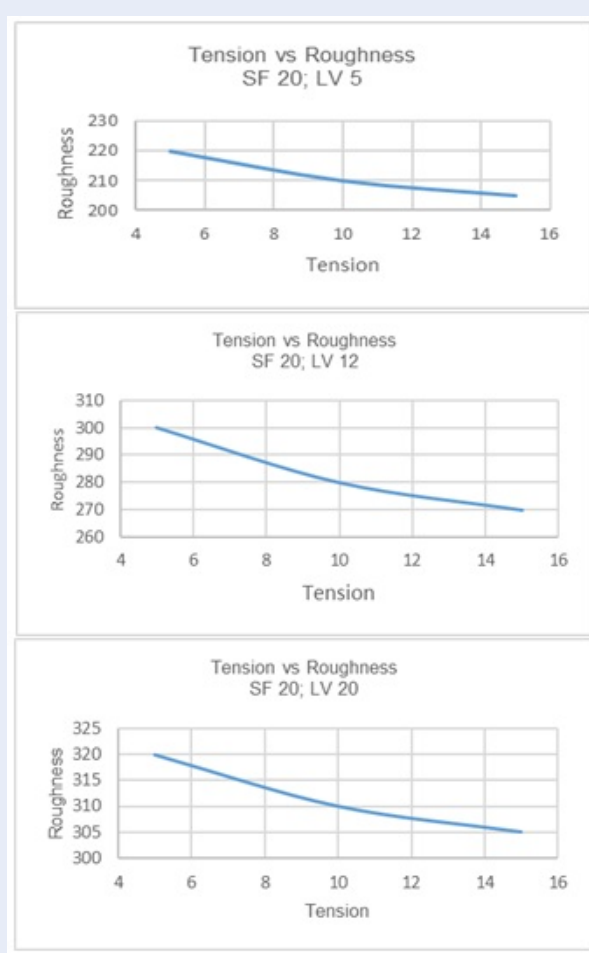

Figure 4: The tension versus roughness with SF: Swing frequency $(\mathrm{Hz})$, LV: Lowering velocity $(\mathrm{m} / \mathrm{m})$.

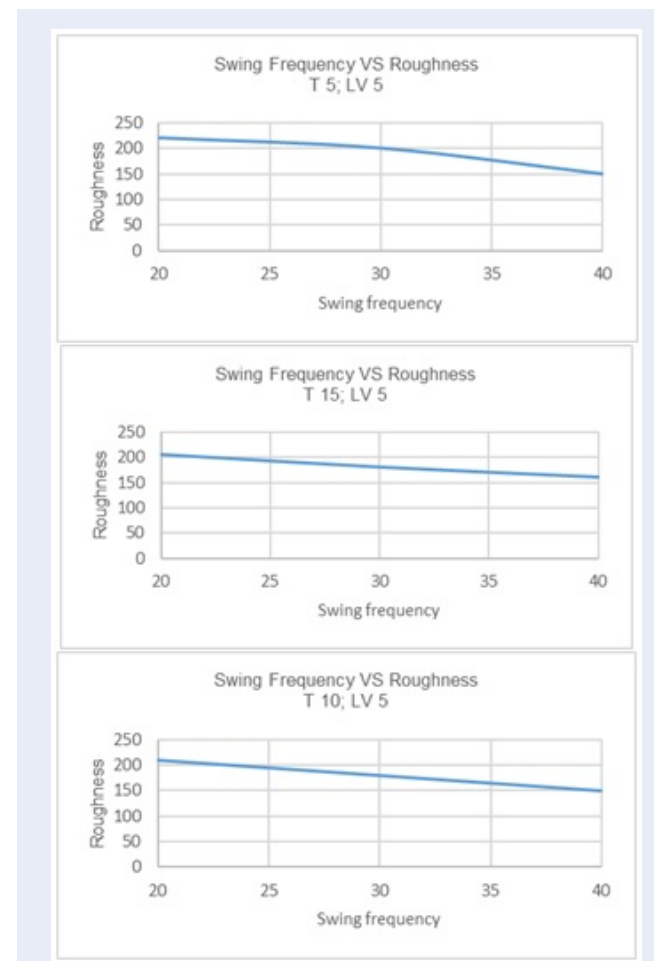

Figure 5: The Swing Frequency versus Roughness with $\mathrm{T}$ : Tension (kgf), LV: Lowering velocity $(\mathrm{m} / \mathrm{m})$. 


\begin{tabular}{|c|c|c|c|c|c|c|}
\hline Groups & Count & & Sum & Average & Variance & \\
\hline Tension & 27 & & 270 & 10 & 17,3 & \\
\hline Frequency & 27 & & 810 & 30 & 69,2 & \\
\hline Velocity & 27 & & 333 & 12,3 & 39 & \\
\hline \multicolumn{7}{|l|}{ ANOVA } \\
\hline Source of Variation & SS & $\mathrm{df}$ & MS & $\mathrm{F}$ & P-value & F crit \\
\hline Between Groups & 6458 & 2 & 3229 & 77,1 & 0 & 3,1 \\
\hline Within Groups & 3264 & 78 & 41,8 & & & \\
\hline Total & 9722 & 80 & & & & \\
\hline
\end{tabular}

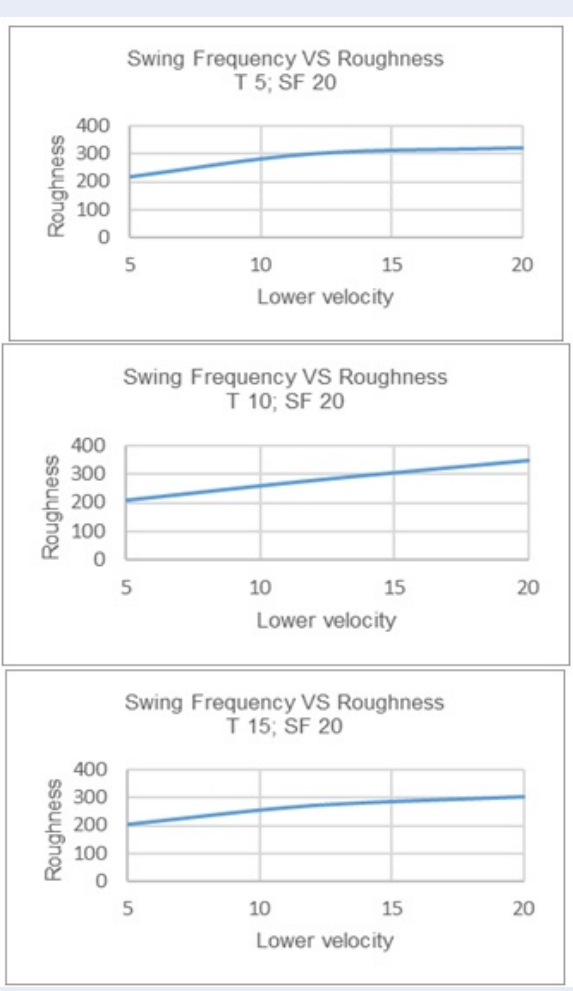

Figure 6: The lowering velocity versus roughness with SF: Swing frequency $(\mathrm{Hz}), \mathrm{T}$ : Tension (kgf)

important role, is very necessary. When operating the cutting machine, the workers can adjust few parameters instead of all of parameters. All parameters are only adjusted at the first time of shift. Few important parameters can be adjusted during operating time.

A correlation coefficient is a numerical method of correlation, which meaning a statistical relationship between two variables. The variables may be two or three groups of a given data set. It is often called a sample, or two or three components of a multivariate random variable with a known distribution. In this paper, correlation coefficient will help to select important parameters for frequently adjustment. After using excel program to calculate the correlation coefficient, the parameter: lower speed, keep as important relation with the surface roughness.

\section{DISCUSSION AND RESULT}

Using the wire for cutting gives a significant method to manufacture the AAC block. To increase the surface quality, some parameters can be adjusted. Although there are about 10 parameters to influence to the surface quality, there are only three main ones: the feed rate, the wire speed and the tension. The best parameters are 5, 40, 5 of tension, swing frequency and lowering velocity respectively. However, the important parameter, speed rate, can be used frequently after others are adjusted by engineers.

\section{CONCLUSION}

The paper introduced three important parameters in the AAC cutting machine: the wire tension, the swing frequency and the lower velocity in increasing the surface quality. The experiments showed that the increase of lowering speed make the wire vibrate stronger and the surface rougher. When the tension of wire is increased, the stiffness of the system is increased too, as a result that the roughness reduces. The vibration amplitude reduces and the surface will be smoother. However, when operating the cutting machine, the important parameter is the lower velocity and workers will operate the cutting machine easier with only one parameter lower velocity.

\section{ACKNOWLEDGEMENTS}

This research was supported by Viet Nam National University Ho Chi Minh City under grant number c2020-20-09. 


\section{LIST OF ABBREVIATIONS}

ANOVA: Analysis Of Variance.

AAC: Autoclaved Aerated Concrete.

\section{COMPETING INTERESTS}

The authors guarantee that there is no conflict of interest in the publication of the article "Study on parameters on cutting AAC by wires".

\section{CONTRIBUTION OF THE AUTHORS}

Tung T. Luu did works in this paper.

\section{REFERENCES}

1. Teomete E. Effect of Process Parameters on Surface Quality for Wire Saw Cutting of Alumina Ceramic. Gcizi University Journal of Science. 2011:24:291-297.

2. Zhu L, Kao I. Galerkin-based modal analysis on the vibration of wire-slurry system in wafer slicing using a wire saw. Journal of Sound and Vibration. 2005;283:589-620. Available from: https: //doi.org/10.1016/j.jsv.2004.04.018.

3. Ge PQ, et al. Development of Endless Diamond Wire Saw and Sawing Experiments. Materials Science Forum. 2004;471472:481-484. Available from: https://doi.org/10.4028/www. scientific.net/MSF.471-472.481.

4. Wei S, Kao I. Vibration analysis of wire and frequency response in the modern wires aw manufacturing process. Journal of Sound and Vibration. 2000;231:1385-1395. Available from: https://doi.org/10.1006/jsvi.1999.2471.

5. Wu H, et al. Effect of Reciprocating Wire Slurry Sawing on Surface Quality and Mechanical Strength of As-Cut Solar Silicon Wafers. Precision Engineering. 2013;

6. Tso PL, et al. Study on Thin Diamond Wire Slicing with Taguchi method. Materials Science Forum. 2006;505507:1219-1224. Available from: https://doi.org/10.4028/www. scientific.net/MSF.505-507.1219. 


\section{Nghiên cứu những thông số cắt gạch bê tông khí chưng áp}

\section{Lưu Thanh Tùng ${ }^{*}$

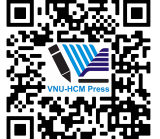

Use your smartphone to scan this QR code and download this article

\section{TÓM TẮT}

Gach bê tông khí chưng áp (AAC) là sản phẩm xây dựng nhe, chiu tải, cách nhiệt cao, bền, được sản xuất với nhiều kích cỡ và độ bền khác nhau. Khối gạch AAC nhẹ khi so với gạch đỏ, khối AAC nhẹ hơn ba lần. Khối gạch AAC đang phát triển nhanh chóng tại Việt Nam. Khối gạch AAC có nhiều ưu điểm hơn như đúc sẵn và xây gạch dễ dàng. AAC được sản xuất từ các nguyên liệu phổ biến là vôi, cát, xi măng và nước, cùng một lượng nhỏ chất tạo khí. Sau khi đó nguyên liệu được trộn và đưa vào khuôn. Sau đó, khối gạch $A A C$ sẽ được cắt thành gạch block bằng dây thép. Khi cắt khối gạch ACC, bề mặt gạch block phải nhẵn để không cần trát vữa. Hơn nữa, độ nhám của bề mặt phải nhỏ hơn $0,1 \mathrm{~mm}$ để sơn tường dễ dàng. Kích thước khối gạch $\mathrm{AAC}$ cũng cần độ chính xác cao để bức tường sẽ thẳng khi xếp các khối gạch $\mathrm{AAC}$ chônng lên nhau. Tuy nhiên, trong bài báo này sẽ chỉ nghiên cứu độ nhám của bề mặt gạch vì độ nhám sẽ quyết định giá thành. Khối gạch AAC được tạo ra bằng cách sử dụng dây thép để cắt các khối AAC lớn thành các khối AAC nhỏ. Ảnh hưởng của các thông số công nghệ đến hiệu suất của quá trình cắt bằng dây thép là tốc độ dây, tốc độ tiến dao và lực căng. Mỗi thổng số sẽ ảnh hưởng đến chất lượng bề mặt với những tác động khác nhau. Ngoài ra, các thông số này ảnh hưởng lẫn nhau, là nguyên nhân gây ra các vết xước trên bề măt khối gach AAC. Các thí nghiệm sẽ được thực hiện để đo chiêu cao của độ nhám với sư thay đổi của tốc độ dây, tốc độ tiến dao và lực căng. Các thông số tốt nhất sẽ được tìm thấy, giúp sản xuất AAC có chất lượng cao hơn.

Từ khoá: Gạch bê tông khí chưng áp, dây thép, độ nhấp nhô
Trường Đại học Bách Khoa -

ĐHQG-HCM, Việt Nam

\section{Liên hệ}

Lưu Thanh Tùng, Trường Đại học Bách Khoa - ĐHQG-HCM, Việt Nam

Email: ttluu@hcmut.edu.vn

Lịch sử

- Ngày nhận: 18-11-2020

- Ngày chấp nhận: 16-3-2021

- Ngày đăng: 30-3-2021

DOI : 10.32508/stdjet.v4i1.795

\section{Check for updates}

\section{Bản quyền}

๑ Đ ĐHQG Tp.HCM. Đây là bài báo công bố mở được phát hành theo các điều khoản của the Creative Commons Attribution 4.0 International license.

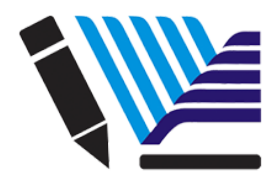

VNU-HCM Press
Trích dẫn bài báo này: Tùng L T. Nghiên cứu những thông số cắt gạch bê tông khí chưng áp. Sci. Tech. Dev. J. - Eng. Tech.; 4(1):731-738. 